\title{
Serpentinisme in French Art of the Second Half of the XIXth Century
}

\author{
Daria Martynova ${ }^{1, *}$
}

\begin{abstract}
${ }^{1}$ Repin Saint-Petersburg State Academic Institute of Painting, Sculpture and Architecture, St. Petersburg, Russia *Corresponding author. Email: d.o.martynova@gmail.com
\end{abstract}

\begin{abstract}
This article is devoted to the study of the medical institutions' influence on the modification of the plot about the Eve's sin in the second half of the XIXth century. In 1896, the inventor of the graphic pun, Henri Avelot, created the caricature "Four arts", singling out "serpentinisme" among artistic trends (such as symbolism). Using this neologism, the cartoonist criticized contemporary art of his time that borrowed physical manifestations of pathologies (for example, hysteria) to create "innovative" art concepts and works. Analyzing major masters' artworks of this period with "serpentine" movements, it can be traced how the development of the health cult and the strengthening of the disciplinary power of hospitals started the process of aestheticizing diseases. As a result, three new iconographic types appeared in French culture: the snake woman; the "Eve's daughter"; the woman and the "phallic serpent", in which the serpent appears as an allegorical embodiment of a doctor. The snake woman image became an aesthetic ideal that permeated all aspects of culture, which was expressed in the neologism "serpentinisme", which ironically brought this trend closer to the artistic direction.
\end{abstract}

Keywords: French art, femme-serpent, Eve's daughter, hysteria, principle of visual analogy

\section{INTRODUCTION}

The snake image has been known since ancient times and carries many connotations, which causes the ambivalence of the snake as a symbol. This reptile was associated with danger, seduction and eroticism, as well as with rebirth, purification and salvation. However, one of the most popular ideas in the second half of the XIXth century was an idea of the "pathological" and tempting femme-serpent (the snake woman) which considered to be even more dangerous and "venomous" than the femme-fatale.

Taking into account the French historical context of the second half of the XIXth century, in which snakes were actively studied and became domestic animals of certain bourgeois houses, and their poison was attributed various medicinal properties [1], this interpretation is quite curious and not clear. In this article, the author analyzes the image of the snake woman in French visual arts of the second half of the XIXth century and shows that the appearance of such an image was facilitated by the struggle of two institutions of disciplinary power: church and medicine.

Having formed into one of the leading state regulatory authority in the XIXth century, the medical institute led a course on the "health policy". An important component of it was a preservation of mental health and the visibility of treatment for the mentally ill.
At the same time, the church institute insisted on its interpretation of mental diseases, which is why doctors were a kind of "struggle" with church dogmas. JeanMartin Charcot, "The Napoleon of the neuroses", who used visual arts to aestheticize and popularize diseases, associated various religious ecstasies and "miracles" with hysterical symptoms. Using the mimetic abilities of hysterical patients, he forced them to copy famous religious paintings [2]. Besides it, such medical demonstrations allowed to observe naked bodies, bypassing various rules of censorship and morality.

By putting artworks in this context, the author will try to prove that painful, "serpentine" movements of hysterical patients, as well as the use of medical institutions of the established plot about the Eve's sin and the tempter, provoked their crossing and the appearance of the image of femme-serpent in French art of the second half of the XIXth century, which, in turn, led to the creation of the ironic neologism "serpentinisme".

\section{II. "INVENTION" OF THE SNAKE WOMAN} IMAGE

The erotic identification of a woman with a snake was first clearly manifested in the scandalous sculpture "Woman bitten by a snake" (1847) by Auguste Clésinger. The marble statue represents a woman dressed only in jewelry and stretched out on a "bed" of 
flowers. The figure's left leg extends beyond the base of the plinth; a similar technique was performed to draw attention to the small bronze snake that originally encircled the ankle. Immediately after the Salon, this important detail was removed, now only the bracelet made in the form of a snake biting its tail indicates a snakebite. The woman's body echoes the serpent's arc: she herself arches her back, throwing her head back not in a painful, but ecstatic state, as indicated by the tightly closed legs that grip the drapery at the womb. She is represented in a state of paroxysm, like a snake writhing on a pedestal among roses, experiencing a sensualized experience.

Accounting such an image, it can be said that Clésinger introduced the snake only to create the impression that Cleopatra was depicted in front of viewers. The sculptor used it to appease a conservative audience, because in fact he depicted his contemporary: the demi-monde Apollonie Sabatier. In fact, the master exposed a cast of her body, covering such a revolutionary step with a traditional allegorical plot; traces of cellulite and creases are visible on the thighs.

However, it was obvious to the public that Clésinger was trying to convey, not a dramatic incident from history, but tangible and real pleasures of his contemporary, as evidenced by the review of the critic in La Revue des Deux Mondes, who was convinced that the woman is writhing not from pain, but from sweet convulsions, coming to the conclusion that both the name and the snake are concessions made for the jury [3].

As a result, portraying painful ecstasy, a peculiar paroxysm inherent in a neurotic and hysterical attack, the sculptor laid the foundation for the aestheticization and objectification of the "pathological" body in French art and gave an erotic context to the connection between the snake and the woman, depriving it of negative connotations.

\section{III. "EVE'S DAUGHTERS" IN FRENCH CULTURE OF THE SECOND HALF OF THE XIXth CENTURY}

The erotic image outlined by Clésinger was decisively formed in the second half of the XIXth century. In addition to the fact that the snake became a relevant subject of empirical researches, realist writers introduced a zoomorphic image of the snake woman: Guy de Maupassant created the novel "Am I Insane?" (1882), in which he compared the protagonist's object of adoration with a snake, and Gustave Flaubert actively created a serpent-human image in "The Temptation of Saint Anthony" (1874).

The constant flirting with the eerie characterizing the second half of the XIXth century, and likening a woman to this reptile were associated with the processes of secularization and de-Christianization. In this setting, not only the formation of various societies and sects, the revival of interest in occultism and Kabbalah took place, but also the adoption of medicine as a government agency that maintained public order. In this regard, psychiatric institutions that acted as correctional facilities were flourishing. Thus, scientifically proving the witch's hysteria, modern church explanatory models of mental illnesses were undermined by the fact that they were associated with a long history of "unscientific" religious theories that stigmatized afflicted women.

Using representative medicine (that is, proving the historicity of a number of diseases through the work of old masters) as a statement of hysterical symptoms and, according to Michel Foucault, creating the aesthetics of diseases, doctors at Salpêtrière Hospital introduced pathological bodies into the French art (for example, Louis Morin identified "The Gates of Hell" sculptures by Auguste Rodin with hysterical bodily distortions of Salpêtrière, likening movements of these women to the serpentine [5]).

As a result, the transgressiveness of insane women became an exciting topic: snake-headed Medusa, suffering Ophelia, demented Salome were attractive objects for artists. Their rampant, bodily sensuality and beauty were also transferred to religious female images. Since the 1880s Eve also became one of the central heroines of erotic and deviant art-related visual works. This was facilitated by the poem "Paradise Lost" by John Milton, in which the ancestress was portrayed alone while committing a sin, which led to an important modification of the plot of the fall of man: responsibility and blame for him were assigned exclusively to Eve.

This theme was continued to develop in the second half of the XIXth century, when the feminist movement began. In 1858, Pierre Hetzel and Louis Larcher described "Eve's daughters", imputing to them danger because of their beauty and coquetry, also indicating that the woman is a servant of the devil and played along with the snake [6]. Consequently, the image of the "traitor" of Eve was transferred to women of the second half of the XIXth century, and a shift was taking place in the "favor" of the woman: she became the culprit of the fall, and not the serpent. In addition, the feminist commitment to maintaining the image of "Eve's daughter" had a negative impact on the image of the progenitress and her daughters: the famous feminist writer Maria Deraismes pointed out that the sin was committed by Eve because of her curiosity, which brought new and useful discoveries and knowledge to the human race [7].

The feminist mindset was supported by Odilon Redon. This was due to his work on illustrations for Flaubert's Saint Anthony from 1888 to the 1890s [8]. 
The writer developed the image of the serpent-human Knufis in detail, becoming interested in Gnosticism and ophites' ideas. In the illustrations "Woman and Serpent" and "Serpent-Halo" Redon depicted occult, ofitic symbols of the snake as a lamp of knowledge and the woman as its guide, who saved mankind from ignorance, demonstrating the benefits of the union of Eve and the serpent.

The final crossing of a woman with a snake and the creation of the "Eve's daughter" image who made a deal with a snake, were made by the cartoonist Alfred Grévin in his album "Daughters of Eve" (1867) [8]. After the publication of this large-scale work, a "snake boom" began in France: the concept of "Eve's daughters" filled the French minds [9]. Feminists pedaled to positive aspects of the ancestress's act, and opponents of the feminist movement pointed to her union with the devil and the tempter. One way or the other, the snake became one of the central female symbols of the second half of the XIXth century. For example, Joseph Péladan in the sarcastic work "Honest women" (1888) suggested that women are servants of the devil, and described their appearance as "serpentine", that is, deceptive [10]. Péladan linked such characteristics to the feminist movement, noting changes within society that triggered stories of selfobsessed rather than family-obsessed ladies.

The frontispiece for this work was created by Fernand Khnopff based on the composition of the book illustrator Jose Roy. It is significant that the reader is presented with a modern "Eve's daughter" in a negligee, high-heeled shoes and black stockings (an attribute of a prostitute that is often found in the images of women by Felicien Rops). This Amazon rides a huge snake, which, relying on her external attributes, replaces the phallus. Despite the bared fangs, burning eyes and menacing appearance of the reptile, the woman playfully looks directly at the viewer, easily holding on to the writhing snake. Thus, the frontispiece not only demonstrates the union of "modern Eve" with temptation and sin, but also her leading and overwhelming role.

Although Khnopff collaborated extensively with Péladan, the latter's favorite was Rops, known for his highly erotic illustrations. Perhaps that is why Khnopff performed two frontispieces for "Honest Women" and "Ishtar", unprecedentedly sensual. In the last frontispiece, the artist naturalistically depicted the woman in height tied to a pillory, indicating an obscure indictment. Her body is arched, her eyes hazy, her mouth open. Her curls flow down, drawing attention to her heaving breasts. At the bottom of her stomach, a monster bursts out, releasing serpentine tentacles into her womb, that hints at simultaneous acts of birth and copulation. Similarly, Khnopff updated a topic that had been troubling Rops for several years: the syphilis epidemic. He reproduced hereditary or congenital syphilis: during this period, the idea was widespread that a woman could be born already infected with the "French disease", since she was infected in the womb [11]. A similar idea of a "born prostitute" coincided with the idea of original sin.

Thus, doctors scientifically proved the biblical idea, due to which the female body began to be perceived as morbid and dangerous. It is worth to note that such a sensualized and disturbing image appeared due to the development of neurology and psychiatry and their influence on the image of Eve and her "daughters".

\section{IV. "THE FIRST NEURASTHENIC" AND THE SNAKE WOMAN IN THE SECOND HALF OF THE XIXth CENTURY}

France is the country of the "Great neurosis", which gave rise to images of female insanity, adopted the term "neurasthenia" from American doctors who invented it in the 1860s. And if the Americans insisted on modernity as the root cause, the French considered this disorder hereditary, often associating it with hysteria: if Eve was the first patient with neurasthenia, then all women should be predisposed to diseases of the nervous spectrum [12].

As a result, Eve was declared the "first neurasthenic" (while portraying her as a modern Parisian), linking her image not only with her historical weakness and sinfulness, but also with the idea that sexual actions and control by a man possibly "heal" her. In this connection, there was a claim that the phallic snake was a doctor sent to cure a patient, which was a reference to the long-held belief that sexual desire or passivity is at the root of many "female" diseases, including hysteria - the final stage of neurosis, and sexual intercourse brought relief to the sufferer of the disease. This misconception was also promoted by the multi-year practice of organizing the "Bal de l'Internat" - a carnival for medical students, closely associated in the minds of contemporaries with deviant behavior, orgies and sexual violence [13]

The "Bal de l'Internat", founded in 1852, was accompanied by dressing in pagan gods and characters, plentiful drinks. Medical students were accompanied by women who were absolutely naked or dressed in minimum clothing, whose behavior was considered deviant (it is worth noting that in most cases students were accompanied by hysterical patients from Salpêtrière)

The idea of a phallic snake that heals sick women has been actively developed in posters and invitations on this theme. In 1906, Gaston Pierre Galey created a poster that demonstrated the hedonism and orgies inherent in this "professional holiday". In the center of groups indulging in drunkenness and debauchery, there 
is a statue of Hippocrates, which a naked woman, writhing in a "hysterical arc", tries to get drunk from a cup. Also next to the "father of medicine" is a python that comes to life and performs a sexually perverted act with its tongue, invading the intimate zone of a distraught and intoxicated woman. Below, the future of the lady is shown: the hysterical bend becomes stronger, she indulges in paroxysms and falls into the arms of students disguised as satyrs, who begin to grope her "healed" body. The idea of the "healing phallic snake" was also depicted by Felicien Rops, ironic in relation to the treatment of patients with hysteria. The famous "Charcot shower" in his drawing "Shower" is shown as the doctor's genital organ, directed to the bosom of an exalted patient.

Rops, the artist of "modern Parisian women", was interested in the themes of the sin of the ancestress and the "Eve's daughters", as evidenced by his detailed analysis of the genesis of these images. If in the early 1880s Rops represented the serpent as the culprit and seducer, for example, in "Woman and a doll", where the snake wraps the font and holds an apple in his mouth, representing the devil, or in "Eve", in which the ancestress accepts the forbidden fruit from him, then in the late 1880 s the artist made Eve the seductress, combining her and the serpent. Rops created the frontispiece "You will be like God" for Joseph Péladan's book "Un Coeur perdu" (1888), depicting naked Eve standing with her back to the tree of knowledge and holding an apple in her hand. The serpent wraps around her body, merging with her. The progenitress's hair is reared, her mouth is open in an exalted scream. That Rops was trying to show a moment of ecstasy, the connection between Eve and the tempter is evidenced by the fact that the serpent's head was initially pointed at her genitals, but the painter decided to remove this detail due to censorship [14]

Later, he did create a drawing showing the sexual relationship of Eve and a reptile seduced by her, continuing the theme of "phallic serpent": in "Eve's Apples", she lies on her back with her head thrown back and open mouth, clinging to the rings of the snake's body with her hands and spreading her legs, exposing the bosom toward which the snake head is heading. In "Temptation or Apple" or "the Devil and Eve in the garden of Eden", the artist created a zoomorphic devil-serpent image, presenting the ancestress as his mistress and accomplice. As a result, Rops finally turned Eve into the first sinner and seductress in the "Spell": her body grows into the tree of knowledge, and a serpent's head appears from it, pointing at Eve's genitals. She again bends in a hysterical arc in an ecstatic state; thus, the artist once more emphasized the insanity of this image and the sexual background of the modern neurological treatment of women's mental diseases.
Subsequently, Rops repeatedly addressed the connection of women with the devil in the works of the cycle "Satanists": thus, in "Golgotha" Satan strangles a woman in a hysterical "crucifixion" position with her hair represented as a snake, and in "Sacrifice" the artist continued to develop the idea of the "phallic snake" and the woman as a "vessel of the devil".

Henri Gerbault continued to develop images of "modern Eve and her partner - snake" in detail in the magazine "La vie Parisienne", presenting the progenitress as a seductress and initiator of a sin, and the snake or python as a subordinate and innocent. For example, in the illustration "Protection from touch", the python is depicted not as a provocateur, but as a defender of the tree of knowledge, who fell under the spell of naked Eve, and in the illustration "Professor" naked Eve looks directly at the viewer, addressing him with the phrase: "Who wants to learn to sin?". In it, as in the "Mademoiselle and Monsieur Adam", the initials "A+E" are inscribed on the tree of knowledge, which indicates the repeated Eve's attempts on the tree. As a result, Gerbault presented the ancestress as the main tempter and the devil's servant, giving these qualities to all women.

Only Henri Toulouse-Lautrec managed to combine the dangerous images of the "Eve's daughter" and the "first neurotic" in the poster "Jane Avril" (1899). "Crazy Jane" as her contemporaries called her, was a patient at Salpêtrière [15]. She suffered from the syndrome of "St. Vitus's dance", inherent in patients with hysteria and characterized by strange movements and swaying. Salpêtrière doctors organized a "Mad Ball" to demonstrate the effectiveness of treatment for patients in which the future cabaret star participated. There, she noticed similarities between her "pathological" movements and rhythmic dance steps. She successfully fit into the trends of popular culture: at this time, one of the most fashionable dances was "epileptic", copying the movements of patients with hystero-epilepsy [16]. By depicting her dancing, Lautrec was essentially aestheticizing her illness.

In his last poster, Lautrec depicted the curved body of Avril in closed and tight black dress, which shows a python as if strangling the dancer at the level of her lower abdomen and approaching her head. In horror, she throws up her hands; this gesture resembles a hysterical bow, which, for example, is depicted in the "Photographic iconography of Salpêtrière". Lautrec created this work based on a photography taken by Paul Cesko, where real dress with an embroidered python (it is worth noting that Avril in the photo dreamily threw her eyes up) is shown. In fact, it depicts not only the latest "fashion trend": the concept of "Eve's daughters" influenced women's clothing and jewelry, which became dominated by serpentine motifs [17], but also "the modern neurotic daughter of the ancestress", 
because the ambivalent image of Eve, including virtues and vices, successfully coincided with the stage role of Avril. In addition, the snake that wraps around the dancer's body may remind her hospital past, as many patients associated doctors with snakes [18].

This manifestation of Avril as the "Eve's daughter" shows how popular and influential this concept was during the time period under consideration. Thus, the fashion for the connection of a woman and a snake was manifested not only in dresses or jewelry, but also in dance movements and stage costumes: Loïe Fuller's famous "serpentine dance" gave rise to many illustrations depicting her as the femme-serpent [19].

\section{FEMME-SERPENT AND SERPENTINISME}

The image of the snake woman affected the entire French culture: this term was increasingly featured in the popular press. Thus, discussing the sensational portrait of Sarah Bernhardt in 1876 in an imaginary dialogue on the pages of the magazine "La Fantaisie Parisienne", the interlocutors came to the conclusion that her curves were similar to those of the femmeserpent, and it would be better if the artist depicted her as a snake, without unnecessary hints [20]. In 1868, the magazine "Les Petites affiches de la mode" distinguished the femme-serpent as a separate type that characterized women [21]. In addition, femme-serpent was closely associated with "pathological" female bodies, namely hysterical ones. This was evidenced by a number of "Bal de l'Internat" images (for example, a poster where a snake penetrates a woman in ecstasy (1924)).

In 1896, the hysteria and zoomorphic image of the female snake was finally connected in the Henri Avelot's cartoon called "Quat'z'Arts", dedicated to the ball of student artists, famous for the participation of nude models. The description of this work reads: "I ordered my portrait to four modernists... the third is hysterical". A woman complains about her images made by artists of different directions: pointillism, tashism, serpentinisme and symbolism. A portrait in the style of "serpentinisme" represents a woman with a snake tail, it stands out for its scale, decorative, spiral and dynamic lines.

Having used the neologism "serpentinisme", the cartoonist criticized his contemporary art, which borrowed the physical manifestations of pathologies (for example, hysteria) to create "innovative" concepts and works. Avelot sarcastically emphasized the differences between artistic novelty and disease, criticizing the aestheticization of pathologies. Having formally stylized the model's hair, arms and body and turned them into decor or interior items, Avelot ridiculed not only painting, but also decorative, applied art and the fashion of his time, showing the penetration of "pathological" snake arabesques into screens, costumes, tapestries or advertising posters.

The popularity of these image and neologism was confirmed by the caricature of 1896 , dedicated to the Salon of "Rose + Croix" [22]. An unknown cartoonist portrayed a bourgeois standing in front of one of paintings presented at the exhibition. He is struck by the image of an unusual girl with naked breasts: her upper body is female, and the lower one is presented in the form of a snake tail. One detail indicates the connection with hysteria: the model inhales the flower's aroma. In the second half of the XIXth century, the aromas of flowers were associated with madness and death, with the suicides of the literary heroines Ophelia and Albine, who went crazy due to unsatisfied desires and traumatic experiences. As a result, such drawings not only confirm the connection of serpentinisme with neurasthenia and hysteria, but also the penetration of the serpentine line into the art of the $1890 \mathrm{~s}$ as a consequence of the development of the image of the femme-serpent and its design into a colloquial characteristic.

\section{CONCLUSION}

Thus, having analyzed the development of the classic story about a woman and a snake in the second half of the XIXth century, it is possible to trace its evolution: from erotic, provocative to painful, "pathological" interpretations expressed by the creation of a sexualized serpent-human image. Art works on this topic not only reflected the latest trends in art culture, but also demonstrated the current socio-cultural processes of modern society.

Thus, in response to the developing feminist movement and the attempts of the state institution of disciplinary authority represented by the hospital to control this process, creating a concept of the initial sinfulness and "pathology" of the female body, artists and graphics modified the biblical story about Eve and the tempter. As a result, three new iconographic types appeared: 1) the snake woman as a vessel of sin, ugliness, and dirt; 2) "Eve's daughter" - an image that characterizes both the cunning and morbidity of a woman of the XIXth century, and her enlightenment and progressiveness; 3 ) the union of a woman and a serpent, in which the serpent appears as a phallic incarnation of a doctor, these allegorical images sarcastically ridiculed the relationship of doctors and patients in modern art works, demonstrating the primacy of patriarchal society.

The similar popularity of these new concepts led to the invention of Henri Avelot's ironic neologism "serpentinisme", which characterized the current trend in artistic culture. This term summed up visual searches and criticized contemporary art, which borrowed physical manifestations of pathologies to create 
"innovative" art concepts and works. As a result, Sshaped body curves, sharp turns, lush and tight clothes, an exalted face, a "pathological" body and "snake" attributes turned the artistic images of real women into "femme-serpent" and "daughters of Eve", which became an "aesthetic ideal permeating all aspects of culture"[23], which was expressed in the neologism "serpentinisme", bringing this tendency closer to the artistic direction.

\section{References}

[1] J. A. Pacyga, "Pythons in Paris: Fear and Desire in the French Empire", Journal of the Western Society for French History, 43, 2015, pp. 145-154.

[2] A. Preez, "Putting on Appearances: Mimetic Representations of Hysteria", De Arte, 69 (39), 2004, pp. 47-61.

[3] G. Planche, "Le Salon de 1847 - La Sculpure", Le Revue des Deux Mondes, 18, 1847, pp. 541-542.

[4] P. Faxneld, "Satanic Feminism: Lucifer as the Liberator of Woman in Nineteenth-Century Culture", Oxford, Oxford University Press, 2017.

[5] L. Morin, "Le raid de Rodin", Le Revue des quat'saisons, 3, 1900, pp. 185-192.

[6] P. J. Martin, L. J. Larcher, "Anthologie satirique le mal que les poets on dit des femmes", Paris, Hetzel, 1858, p.7.

[7] M. Deraismes, "Éve dans l'humanité", Paris, L. Klejman, 1868.

[8] E. Emery, L. Postlewate, "Medieval Saints in Late Nineteenth Century French Culture: Eight Essays", Jefferson, N.C., McFarland \& Co, pp. 73-74.

[9] A. Grévin, "Les Filles d'Eve", Paris, Bureaux du Journal Amusant, 1867.

[10] J. Péladan, "Femmes honnêtes", Paris, C. Dalou, 1888.

[11] R. Neginsky, "Mental Illnesses in Symbolism", 2017, Cambridge, Cambridge Scholars Publishing, pp. 49-51.

[12] A. Rabinbach, "The Human Motor: Energy, Fatigue, and the Origins of Modernity", Berkeley, California, University of California Press, 1992, pp. 154-155.

[13] L. Kerley, "Merriment, Medical Humor, and Masculinity at the Bal de l'Internat", 1897-1911. Nineteenth-Century Art Worldwide 13, 2, 2014, pp. 87-102.

[14] E. Hoffmann, "Rops: peintre de la femme modern", The Burlington Magazine, 974 (126), 1984, pp. 264-265.

[15] M. De Lafayette, "Jane Avril Queen of the French Can Can", Paris, New York, Times Square Press, 2015, pp. 17-21.

[16] R. B. Gordon, "From Charcot to Charlot: Unconscious Imitation and Spectatorship in French Cabaret and Early Cinema", Critical Inquiry, 3(27), 2001, pp. 515-549.

[17] G. P. Weisberg, "Montmartre and the Making of Mass Culture", New Jersey, Rutgers University Press, 2001, p. 63.

[18] C. Eidenbenz, "Les mots de l'hystérie: de la Salpêtrière au serpentinisme", Namur, Musée Félicien Rops, Waterloo, Renaissance du Livre, 2012, p. 164.

[19] R. Tardivaux, "La Loie Fuller", Gil Blas Illustré, December 18, 1892, pp. 2-3.

[20] Unknown author, "L'exposition: lui et elle", La fantaisie Parisienne, Mai 15, 1876, p. 2.

[21] Unknown author, "La musique au jardin des Tuileries", Les Petites affiches de la mode, Juillet, 1868, p. 9.
[22] D. Delille, "Demystifier le mystique: Josephine Péladan et les cercles rosicrucines a l'epreuve du rire fin de siècle", Romantisme, Armand Colin, 2012, pp. 90-91.

[23] F. Wildschut, K. Clevis, "Ophelia: Sehnsucht, Melancholia and Desire for Death", Amsterdam, Uitgeverij de Buitenkant, 2009, pp. 266-267. 